\title{
PENGARUH UKURAN PERUSAHAAN, LABA/RUGI PERUSAHAAN, DAN OPINI AUDIT TERHADAP AUDIT DELAY PADA PERUSAHAAN MANUFAKTUR YANG TERDAFTAR DI BURSA EFEK INDONESIA
}

\author{
Inda Qoriah Fatimah ${ }^{1}$, Endang Sri Mulatsih ${ }^{2}$ \\ Sekolah Tinggi Ilmu Ekonomi Mulia Darma Pratama Palembang \\ indafatimah97@gmail.com¹, endangsrimulatsih21@ gmail.com²
}

\begin{abstract}
ABSTRAK
Audit delay adalah lamanya hari yang dibutuhkan auditor untuk menyelesaikan pekerjaan auditnya, diukur dari tanggal penutupan tahun buku hingga tanggal diterbitkannya laporan audit. Audit delay memiliki faktor-faktor yang mempengaruhi diantaranya ukuran perusahaan, laba/rugi perusahaan, dan opini audit. Perumusan dalam masalah penelitian bagaimana pengaruh ukuran perusahaan, laba/rugi perusahaan, dan opini audit secara simultan serta parsial terhadap audit delay. Tujuan penelitian ini mengetahui pengaruh ukuran perusahaan, laba/rugi perusahaan, dan opini audit secara simultan serta parsial terhadap audit delay. Metode dalam penelitian ini menggunakan analistis deskriptif dan verifikatif. Hasil penelitian menunjukkan bahwa: ukuran perusahaan tidak berpengaruh negatif terhadap audit delay, ditunjukkan nilai $t_{\text {hitung }}-1,403$ berada diantara $t_{\text {tabel }}$ atau $-3,375 \leq t_{\text {tabel }} \leq 3,375$ dan signifikasi lebih kecil dari 0,05 $(0,001<0,005)$. Laba/rugi perusahaantidak berpengaruh terhadap audit delay, ditunjukannilai $t_{\text {hitung }}-0,748$ berada diantara $t_{\text {tabel }}$ atau $-3,375 \leq t_{\text {tabel }} \leq 3,375$ dan signifikasi lebih kecil dari 0,05 $(0,001<0,005)$. opini audit tidak berpengaruh terhadap audit delay, ditunjukkan nilai $t_{\text {hitung }}$ 0,994 berada diantara $t_{\text {tabel }}$ atau-3,375 $\leq t_{\text {tabel }} \leq 3,375$ dan signifikasi lebih kecil dari $0,05(0,001$ $<0,005)$.
\end{abstract}

Kata Kunci : Ukuran Perusahaan, Laba/Rugi Perusahaan, Opini Audit, Audit Delay.

\begin{abstract}
Audit delay is the length of day that auditors need to complete their audit work, measured from the closing date of the book year until the date of publication of the audit report. The audit delay has factors affecting the company's size, profit/loss, and audit opinions. Problem formulation in the research is how the influence of the company size,companyprofit/loss, and the audit opinion simultaneously as well as partially toward the audit delay. The purpose of this research is to know the influence of company size, profit/loss of the company, and the audit opinion simultaneously as well as partially toward the audit delay. The methods in this study use both descriptive and verificativeanalytics. The results showed that: the size of the company has no negative effect on the audit delay, indicated by the value of Tcount -1.403 between $t$ table or-3.375 $\leq t$ table $\leq 3.375$ and the signification is smaller than $0.05(0.001<0.005)$. Profit/loss company does not affect the audit delay, shown by the value of Tcount-0.748 is located between $t$ table or-3.375 $\leq t$ table $\leq 3.375$ and the signification is smaller than 0.05 (0.001 < 0.005). Audit opinion does not affect the audit delay, indicated by the value of T count0.994 is between $t$ table or $-3.375 \leq t$ table $\leq 3.375$ and the significance is smaller than 0.05 $(0.001<0.005)$.
\end{abstract}

Keywords : Company Size, Profit/Loss Company, Opinion Audit, Audit Delay. 


\section{PENDAHULUAN}

Perusahaan-perusahaan saat ini semakin berkembang pesat. Salah satu indikator yang membuat perusahaan semakin berkembang dan dikenal secara luas yaitu dengan go public. Perusahaan go public harus terdaftar di Bursa Efek Indonesia (BEI) dengan beberapa ketentuan yang sudah diatur. Berdasarkan keputusan ketua badan pengawas pasar modal (BAPEPAM) dan lembaga keuangan nomor kep-346/BL/2011 peraturan nomor X.K.2 tentang penyajian laporan keuangan menyatakan bahwa perusahaan go publik yang terdaftar di Bursa Efek Indonesia wajib menyampaikan laporan keuangan tahunan kepada Bapepam dan Lembaga Keuangan (LK) serta mengumumkan kepada masyarakat paling lambat pada akhir bulan ketiga setelah tanggal laporan keuangan tahunan berdasarkan standar akuntansi keuangan dan diaudit oleh akuntan publik yang terdaftar di Bapepam dan Laporan Keuangan.

Laporan keuangan adalah salah satu media komunikasi keuangan antara manajemen perusahaan dan stakeholder (Margaretta dan Soepriyanto). Laporan keuangan memiliki peran yang sangat penting untuk mengukur kinerja suatu perusahaan, karena di dalam laporan keuangan terdapat informasi mengenai posisi keuangan, kinerja perusahaan, serta perubahan posisi keuangan suatu perusahaan. Laporan keuangan perusahaan yang disampaikan ke Bapepam harus disertai laporan audit oleh akuntan publik.

Setelah laporan keuangan selesai disusun oleh perusahaan masih harus menjalani proses audit oleh auditor independen. Pemenuhan standar audit oleh auditor dapat berdampak lamanya penyelesaian laporan audit, tetapi juga berdampak peningkatan kualitas hasil audit. Pelaksanaan audit yang semakin sesuai dengan standar membutuhkan waktu semakin lama.

Berdasarkan pada Standar Profesional Akuntan Publik (SPAP), kompartemen akuntan publik, Ikatan
Akuntan Indonesia (IAI, 2001) khususnya tentang standar pekerjaan lapangan mengatur tentang prosedur dalam penyelesaian pekerjaan lapangan seperti perlu adanya perencanaan atas aktivitas yang akan dilakukan, pemahaman yang memadai atas struktur pengendalian intern dan pengumpulan bukti-bukti kompeten yang diperoleh melalui inspeksi, pengamatan, pengajuan pertanyaan dan konfirmasi sebagai dasar untuk menyatakan pendapat atas laporan keuangan.

Semakin panjang waktu yang dibutuhkan untuk proses audit, maka semakin besar kemungkinan bahwa perusahaan terlambat menyampaikan laporan keuangan ke Bapepam dan para pengguna laporan keuangan lainnya. Pemeriksaan laporan keuangan oleh auditor independen untuk menilai kewajaran penyajian laporan keuangan membutuhkan waktu yang cukup lama, karena banyaknya transaksi yang harus diaudit, kerumitan dari transaksi, dan pengendalian internal yang kurang baik. Hal ini yang menyebabkan audit delay semakin meningkat.

Berdasarkan uraian latar belakang di atas, maka peneliti tertarik mengambil judul penelitian mengenai "PENGARUH UKURAN PERUSAHAAN, LABA/RUGI PERUSAHAAN, DAN OPINI AUDIT TERHADAP AUDIT DELAY PADA PERUSAHAAN MANUFAKTUR YANG TERDAFTAR DI BURSA EFEK INDONESIA"

\section{METODOLOGI PENELITIAN}

\subsection{Faktor-faktor Mempengaruhi Audit Delay}

yang

\section{Ukuran Perusahaan}

Ukuran Perusahaan adalah besar atau kecilnya suatu perusahaan yang dinilai dari berbagai cara antara lain dinyatakan dengan jumlah kekayaan (total assets), nilai pasar saham, jumlah tenaga kerja, dan total nilai buku tetap perusahaan. Hal tersebut sesuai dengan hasil dari penelitian yang dilakukan oleh Yuliyanti (2011) yang 
menyebutkan bahwa ukuran perusahaan berpengaruh signifikan terhadap audit delay, karena semakin besar perusahaan maka semakin baik pula pengendalian internal perusahaan tersebut sehingga dapat mengurangi tingkat kesalahan dalam penyajian laporan keuangan yang akan memudahkan auditor dalam melakukan pengauditan atas laporan keuangan tersebut.

\section{Laba/Rugi Perusahaan}

Laba/rugi perusahaan yang mana setiap kerugian yang didapatkan akan menunda laporan keuangan perusahaan yang menyebabkan audit delay, sebaliknya jika perusahaan mendapatkan laba yang tinggi maka perusahaan akan mempercepat auditnya. Seperti penelitian yang dilakukan Kartika (2009) laba/rugi perusahaan mempunyai pengaruh negatif dan signifikan terhadap audit delay.

\section{Opini Audit}

Opini audit merupakan opini yang diberikan auditor tentang kewajaran penyajian laporan keuangan perusahaan tempat auditor melakukan audit. Seperti penelitian yang dilakukan Arifatun (2013) dan Kartika (2009) bahwa opini audit berpengaruh negatif terhadap audit delay, karenaperusahaan yang tidak menerima opini audit standar unqualified opinion diperkirakan mengalami audit delay yang lebih panjang alasannya perusahaan yang menerima opini tersebut memandang sebagai bad news dan akan memperlambat proses audit. Disamping itu penerimaan opini selain qualified merupakan indikasi terjadinya konflik antara auditor dan perusahaan yang pada akhirnya memperpanjang audit delay. Jadi, perusahaan yang tidak menerima opini audit standar unqualified opinion mengalami audit delay yang panjang.

\subsection{Objek Penelitian}

Locus pada penelitian ini adalah sub sektor pertambangan yang terdaftar di Bursa Efek Indonesia periode 2017.
Objek pada penelitian ini adalah laporan keuangan pada sub sektor pertambangan yang terdaftar di Bursa Efek Indonesia periode 2017.

\subsection{Populasi dan Sampel Populasi}

Populasi adalah keseluruhan subjek penelitian (Arikunto, 2010:173). Berdasarkan pernyataan tersebut, populasi dalam penelitian ini adalah perusahaan yang terdaftar di Bursa Efek Indonesia khususnya sektor pertambangan.

\section{Sampel}

Sampel adalah bagian dari jumlah dan karakteristik yang dimiliki oleh populasi tersebut (Sugiyono, 2009:91). Dalam penelitian ini, teknik yang digunakan untuk pengambilan sampel adalah dengan menggunakan metode purposive sampling yaitu merupakan teknik pemilihan sampel secara tidak acak yang informasinya diperoleh dengan menggunakan kriteria tertentu. (Sugiyono, 2009:216). Kriteria-kriteria tersebut dalam penelitian ini sebagai berikut:

1) Perusahaan pertambangan yang mengalami laba/rugi.

2) Perusahaan pertambangan yang total aset perusahaan mengalami peningkatan setiap tahunnya.

3) Perusahaan pertambangan yang telah menyampaikan laporan keuangan tahunan yang berisi data dan informasi yang dapat digunakan dalam penelitian ini, serta laporan keuangan tersebut telah diaudit dan disertai dengan laporan auditor independen.

\subsection{Teknik Pengumpulan Data}

Metode pengumpulan data dalam penelitian ini menggunakan metode dokumentasi. Metode dokumentasi dilakukan dengan cara menyalin dan mengarsip data-data dari sumber yang tersedia yaitu berupa data sekunder yang diperoleh dari situs Bursa Efek Indonesia di www.idx.co.id. Data sekunder yang diperoleh yaitu berupa laporan keuangan 
perusahaan yang telah diaudit. Data sekunder juga diperoleh dari jurnal, artikel, dan literatur yang berkaitan dengan penelitian.

\subsection{Metode Analisis Data}

Metode analisis data dalam penelitian ini menggunakan teknik analisis deskriptif dan verifikatif. Metode deskriptif yaitu metode dimulai dengan cara mengumpulkan data, mencatat data, mengklarifikasikan data, dan menganalisis databerdasarkan permasalahan yang telah dirumusakan dan kemudian menarik kesimpulannya. (Sugiyono, 2013:55). Metode verifikatif adalah penelitian yang dilakukan terhadap populasi atau sampel tertentu dengan tujuan untuk menguji hipotesis yang telah ditetapkan. (Sugiyono, 2013:8).

\section{ANALISIS DAN PEMBAHASAN}

\section{Perkembangan Ukuran Perusahaan Manufaktur yang Terdaftar Di Bursa Efek Indonesia.}

Modugu, et al dalam penelitian Arifatun (2013) ukuran perusahaan dapat dihitung menggunakan logaritma (log) dalam penelitian ini dimaksud kan untuk mengurangi fluktuasi data yang berlebih.

\section{Tabel 1}

Ukuran Perusahaan Subsektor Pertambangan Periode 2017 (Disajikan Dalam Jutaan Rupiah)

\begin{tabular}{|c|c|c|c|c|}
\hline No & Nama Perusahaan & Keterangan & Tahun 2017 & Ukuran Perusahaan \\
\hline \multirow{3}{*}{1} & \multirow{3}{*}{ Adaro Energy Tbk } & Aset lancar & $27,708,268$ & \multirow[t]{3}{*}{ (2) } \\
\hline & & Aset tidak lancar & $67,689,790$ & \\
\hline & & Total Aset & $95,398,058$ & \\
\hline \multirow{3}{*}{2} & \multirow{3}{*}{ Atlas Resources Tbk } & Aset lancar & 551,726 & \multirow{3}{*}{15} \\
\hline & & Aset tidak lancar & $4,027,044$ & \\
\hline & & Total Aset & $\mathbf{4 , 5 7 8 , 7 7 0}$ & \\
\hline \multirow{3}{*}{3} & \multirow{3}{*}{ ATPK Resources Tbk } & Aset lancar & 42,058 & \multirow{3}{*}{14} \\
\hline & & Aset tidak lancar & 962,343 & \\
\hline & & Total Aset & $1,004,852$ & \\
\hline \multirow{3}{*}{4} & \multirow{3}{*}{ Borneo Lumbung Energy \& Metal Tbk } & Aset lancar & $4,824,729$ & \multirow{3}{*}{16} \\
\hline & & Aset tidak lancar & $9,026,223$ & \\
\hline & & Total Aset & $13,850,952$ & \\
\hline \multirow{3}{*}{5} & \multirow{3}{*}{ Baramulti Suksessarana Tbk } & Aset lancar & $1,104,221$ & \multirow{3}{*}{15} \\
\hline & & Aset tidak lancar & $1,837,702$ & \\
\hline & & Total Aset & $2,941,923$ & \\
\hline \multirow{3}{*}{6} & \multirow{3}{*}{ Bumi Resources Tbk } & Aset lancar & $10,613,171$ & \multirow{3}{*}{18} \\
\hline & & Aset tidak lancar & $41,137,809$ & \\
\hline & & Total Aset & $51,750,980$ & \\
\hline \multirow{3}{*}{7} & \multirow{3}{*}{ Bayan Resources Tbk } & Aset lancar & $4,339,262$ & \multirow{3}{*}{16} \\
\hline & & Aset tidak lancar & $8,104,121$ & \\
\hline & & Total Aset & $12,443,383$ & \\
\hline \multirow{3}{*}{8} & \multirow{3}{*}{ Darma Henwa Tbk } & Aset lancar & $1,647,246$ & \multirow{3}{*}{16} \\
\hline & & Aset tidak lancar & $3,977,956$ & \\
\hline & & Total Aset & $5,625,202$ & \\
\hline \multirow{3}{*}{9} & \multirow{3}{*}{ Delta Dunia Makmur Tbk } & Aset lancar & $4,940,786$ & \\
\hline & & Aset tidak lancar & $8,297,352$ & 16 \\
\hline & & Total Aset & $13,238,139$ & \\
\hline & & Aset lancar & $5,806,958$ & \\
\hline 10 & Golden Energy Mines Tbk & Aset tidak lancar & $2,459,612$ & 16 \\
\hline & & Total Aset & $8,266,571$ & \\
\hline & & Aset lancar & 46,541 & \\
\hline 11 & Garda Tujuh Buana Tbk & Aset tidak lancar & 785,967 & 14 \\
\hline & & Total Aset & $\mathbf{8 3 2 , 5 0 8}$ & \\
\hline & & Aset lancar & $4,407,197$ & \\
\hline 12 & Harum Energy Tbk & Aset tidak lancar & $2,025,005$ & 16 \\
\hline & & Total Aset & $6,432,202$ & \\
\hline & & Aset lancar & $11,157,944$ & \\
\hline 13 & Indo Tambangraya Megah Tbk & Aset tidak lancar & $7,863,338$ & 17 \\
\hline & & Total Aset & $19,021,282$ & \\
\hline 14 & Resources Alam Indonesia Tbk & Aset lancar & 40,876 & 14 \\
\hline
\end{tabular}




\begin{tabular}{|c|c|c|c|c|}
\hline & & Aset tidak lancar & 907,795 & \\
\hline & & Total Aset & 948,671 & \\
\hline \multirow{3}{*}{15} & \multirow{3}{*}{ Mitrabara Adiperdana Tbk } & Aset lancar & $1,519,763$ & \multirow{3}{*}{15} \\
\hline & & Aset tidak lancar & 731,141 & \\
\hline & & Total Aset & $2,250,904$ & \\
\hline \multirow{3}{*}{16} & \multirow{3}{*}{ Samindo Resources Tbk } & Aset lancar & $1,203,485$ & \multirow{3}{*}{14} \\
\hline & & Aset tidak lancar & 701,465 & \\
\hline & & Total Aset & $1,904,950$ & \\
\hline \multirow{3}{*}{17} & \multirow{3}{*}{ Perdana Karya Perkasa Tbk } & Aset lancar & 41,985 & \multirow{3}{*}{12} \\
\hline & & Aset tidak lancar & 95,377 & \\
\hline & & Total Aset & 137,362 & \\
\hline \multirow{3}{*}{18} & \multirow{3}{*}{ Tambang Batubara Bukit Asam Tbk } & Aset lancar & $11,117,745$ & \multirow{3}{*}{17} \\
\hline & & Aset tidak lancar & $10,869,737$ & \\
\hline & & Total Aset & $21,987,482$ & \\
\hline \multirow{3}{*}{19} & \multirow{3}{*}{ Petrosea Tbk } & Aset lancar & $2,255,176$ & \\
\hline & & Aset tidak lancar & $3,860,640$ & 16 \\
\hline & & Total Aset & $6,115,816$ & \\
\hline & & Aset lancar & $1,404,916$ & \\
\hline 20 & Toba Bara Sejahtera Tbk & Aset tidak lancar & $3,471,815$ & 15 \\
\hline & & Total Aset & $4,876,731$ & \\
\hline & & Aset lancar & 601,519 & \\
\hline 21 & Ratu Prabu Energy Tbk & Aset tidak lancar & $1,904,529$ & 15 \\
\hline & & Total Aset & $2,506,048$ & \\
\hline & & Aset lancar & $2,379,465$ & \\
\hline 22 & Elnusa Tbk & Aset tidak lancar & $2,475,904$ & 15 \\
\hline & & Total Aset & $4,855,369$ & \\
\hline & & Aset lancar & $3,390,980$ & \\
\hline 23 & Energy Mega Persada Tbk & Aset tidak lancar & $7,201,444$ & 16 \\
\hline & & Total Aset & $10,592,424$ & \\
\hline & & Aset lancar & $1,215,117$ & \\
\hline 24 & Surya Esa Perkasa Tbk & Aset tidak lancar & $10,276,002$ & 16 \\
\hline & & Total Aset & $11,491,119$ & \\
\hline & & Aset lancar & $27,650,701$ & \\
\hline 25 & Medco energi Internasional Tbk & Aset tidak lancar & $44,600,300$ & 18 \\
\hline & & Total Aset & $72,251,001$ & \\
\hline & & Aset lancar & 473,183 & \\
\hline 26 & Radiant Utama Interinsco Tbk & Aset tidak lancar & 486,164 & 14 \\
\hline & & Total Aset & 959,347 & \\
\hline & & Aset lancar & $9,001,938$ & \\
\hline 27 & Aneka Tambang Tbk & Aset tidak lancar & $21,012,334$ & 17 \\
\hline & & Total Aset & $30,014,273$ & \\
\hline & & Aset lancar & 770,160 & \\
\hline 28 & Cita Mineral Investindo tbk & Aset tidak lancar & $1,908,089$ & 15 \\
\hline & & Total Aset & 2.678 .249 & \\
\hline & & Aset lancar & 569.197 & \\
\hline 29 & Citra kebun Raya Agri Tbk & Aset tidak lancar & 261 & 13 \\
\hline & & Total Aset & 569.459 & \\
\hline & & Aset lancar & 495,209 & \\
\hline 30 & Central Omega Resources Tbk & Aset tidak lancar & $1,772,345$ & 15 \\
\hline & & Total Aset & $2,267,554$ & \\
\hline & & Aset lancar & $8,358,784$ & \\
\hline 31 & Vale Indonesia Tbk & Aset tidak lancar & $22,225,042$ & 17 \\
\hline & & Total Aset & $30,583,826$ & \\
\hline & & Aset lancar & $1,812,208$ & \\
\hline 32 & J Resources Asia Pasifik Tbk & Aset tidak lancar & $11,085,290$ & 16 \\
\hline & & Total Aset & $12,897,298$ & \\
\hline & & Aset lancar & $6,996,966$ & \\
\hline 33 & Timah Tbk & Aset tidak lancar & $4,879,343$ & 16 \\
\hline & & Total Aset & $11,876,309$ & \\
\hline & & Aset lancar & 417,419 & \\
\hline 34 & Citatah Tbk & Aset tidak lancar & 282,831 & 11 \\
\hline & & Total Aset & 700,250 & \\
\hline & & Aset lancar & 157,296 & \\
\hline 35 & Mitra Investindo Tbk & Aset tidak lancar & 76,430 & 12 \\
\hline & & Total Aset & 233,726 & \\
\hline
\end{tabular}


Berdasarkan tabel 1 di atas ukuran perusahaan manufaktur sub sektor pertambangan pada tahun 2017 yang diproksi dengan total aset yang dimana terlihatperusahaan yang memiliki total aset terkecil hingga terbesar. Total aset yang dihasilkan adalah sebesar Rp.137.362.000.000

Rp.95.398.058.000.000. Dimana total aset tersebut di ukur menggunakan Lnyang menghasilkan ukuran perusahaan seperti perusahaan Citatah Tbk $=14$, Mitra Investindo tbk dan Perdana Karya Perkasa Tbk $=12$, Central Omega Resources Tbk, Elnusa Tbk, Ratu Prabu Energy Tbk, Toba Bara Sejahtera Tbk, Mitrabara Adiperdana Tbk, Baramulti Suksessarana Tbk, dan Atlas Resources Tbk $=15$, Timah Tbk, J Resources Asia Pasifik Tbk, Surya Esa
Perkasa Tbk, Energy Mega Persada Tbk, Petrosea Tbk, Harum Energy Tbk, Bayan Resources Tbk, Darma Henwa Tbk, Delta Dunia Makmur Tbk $=16$, Vale Indonesia Tbk, Aneka Tambang Tbk, Tambang Batubara Bukit Asam Tbk, Indo Tambangraya Megah Tbk $=17$, Medco energi Internasional Tbk, Bumi Resources Tbk, dan Adaro Energy Tbk $=18$.

Perkembangan Laba/Rugi Perusahaan Manufaktur yang Terdaftar Di Bursa Efek Indonesia.

Laba/rugi perusahaan dalam variabel ini diukur dengan skala nominal menggunakan variabel dummy yaitu untuk perusahaan yang mengalami kerugian diberi kode dummy 0 dan untuk perusahaan mengalami laba diberi kode dummy 1. (Kartika, 2009).

Tabel 2

Laba/rugi Perusahaan

SubSektor Pertambangan Periode 2017

(Dalam Jutaan Rupiah)

\begin{tabular}{|c|c|c|c|}
\hline No & Nama Perusahaan & Laba/Rugi Periode 2017 & Keterangan \\
\hline 1 & Adaro Energy Tbk & $7,510,132$ & 1 \\
\hline 2 & Atlas Resources Tbk & $-234,038$ & 0 \\
\hline 3 & ATPK Resources Tbk & $-309,129$ & 0 \\
\hline 4 & Borneo Lumbung Energy \& Metal Tbk & 480,529 & 1 \\
\hline 5 & Baramulti Suksessarana Tbk & $1,159,437$ & 1 \\
\hline 6 & Bumi Resources Tbk & $3,395,196$ & 1 \\
\hline 7 & Bayan Resources Tbk & $4,732,240$ & 1 \\
\hline 8 & Darma Henwa Tbk & 38,767 & 1 \\
\hline 9 & Delta Dunia Makmur Tbk & 654,462 & 1 \\
\hline 10 & Golden Energy Mines Tbk & $1,681,484$ & 1 \\
\hline 11 & Garda Tujuh Buana Tbk & 468 & 1 \\
\hline 12 & Harum Energy Tbk & 780,472 & 1 \\
\hline 13 & Indo Tambangraya Megah Tbk & $3,537,842$ & 1 \\
\hline 14 & Resources Alam Indonesia Tbk & 188,159 & 1 \\
\hline 15 & Mitrabara Adiperdana Tbk & 820,899 & 1 \\
\hline 16 & Samindo Resources Tbk & 172,288 & 1 \\
\hline 17 & Perdana Karya Perkasa Tbk & $-10,440$ & 0 \\
\hline 18 & Tambang Batubara Bukit Asam Tbk & $4,547,232$ & 1 \\
\hline 19 & Petrosea Tbk & 116,354 & 1 \\
\hline 20 & Toba Bara Sejahtera Tbk & 579,178 & 1 \\
\hline 21 & Ratu Prabu Energy Tbk & 28,883 & 1 \\
\hline 22 & Elnusa Tbk & 250,754 & 1 \\
\hline 23 & Energy Mega Persada Tbk & 206,935 & 1 \\
\hline 24 & Surya Esa Perkasa Tbk & 30,677 & 1 \\
\hline 25 & Medco energi Internasional Tbk & $2,179,088$ & 1 \\
\hline 26 & Radiant Utama Interinsco Tbk & 20,922 & 1 \\
\hline 27 & Aneka Tambang Tbk & 136,503 & 1 \\
\hline 28 & Cita Mineral Investindo tbk & 47,493 & 1 \\
\hline 29 & Citra kebun Raya Agri Tbk & $-260,062$ & 0 \\
\hline 30 & Central Omega Resources Tbk & $-44,593$ & 0 \\
\hline 31 & Vale Indonesia Tbk & $-213,794$ & 0 \\
\hline 32 & J Resources Asia Pasifik Tbk & 222,572 & 1 \\
\hline 33 & Timah Tbk & 502,417 & 1 \\
\hline 34 & Citatah Tbk & 4,716 & 1 \\
\hline 35 & Mitra Investindo Tbk & $-23,354$ & 0 \\
\hline
\end{tabular}


Berdasarkan tabel 2 di atas perusahaan manufaktur subsektor pertambangan pada tahun 2017 yang mengalami laba sebanyak 28 perusahaan yang terdiri dari Adaro Energy Tbk, Borneo Lumbung Energy \& Metal Tbk, Baramulti Suksessarana Tbk, Bumi Resources Tbk, Bayan Resources Tbk, Darma Henwa Tbk, Delta Dunia Makmur Tbk, Golden Energy Mines Tbk, Garda Tujuh Buana Tbk, Harum Energy Tbk, Indo Tambangraya Megah Tbk, Resources Alam Indonesia Tbk, Mitrabara Adiperdana Tbk, Samindo Resources Tbk, Tambang Batubara Bukit Asam Tbk, Petrosea Tbk, Toba Bara Sejahtera Tbk, Ratu Prabu Energy Tbk, Elnusa Tbk, Energy Mega Persada Tbk, Surya Esa Perkasa Tbk, Medco energi Internasional Tbk, Radiant Utama Interinsco Tbk, Aneka Tambang Tbk, Cita Mineral Investindo Tbk,yang dimana perusahaan yang mengalami laba diberi kode dummy 1.

Selain mengalami laba ada juga perusahaan yang mengalami rugi sebanyak 7 perusahaan terdiri dari perusahaan Atlas Resources Tbk, ATPK Resources Tbk, Perdana Karya Perkasa Tbk, Citra kebun Raya Agri Tbk, Central Omega Resources Tbk, Vale Indonesia Tbk, dan Mitra Investindo Tbk. Yang dimana perusahaan yang mengalami rugi diberi kode dummy 0 .

Perkembangan Opini Audit Perusahaan Manufaktur yang Terdaftar Di Bursa Efek Indonesia.

Pada variabel ini diukur dengan dummy yaitu untuk opini wajar tanpa pengecualian (unqualified opinion) diberi kode dummy 1 sedangkan untuk opini selain wajar tanpa pengecualian (unqualified opinion) diberi kode dummy 0. (PSA 29 SA seksi 508).

Tabel 3

Opini Audit Sub Sektor Pertambangan Periode 2017

\begin{tabular}{|c|c|c|c|}
\hline No & Nama Perusahaan & Opini Auditor Tahun 2017 & Keterangan \\
\hline 1 & Adaro Energy Tbk & Unqualified opinion & 1 \\
\hline 2 & Atlas Resources Tbk & Unqualified opinion & 1 \\
\hline 3 & ATPK Resources Tbk & Unqualified opinion & 1 \\
\hline 4 & Borneo Lumbung Energy \& Metal Tbk & Unqualified opinion & 1 \\
\hline 5 & Baramulti Suksessarana Tbk & Unqualified opinion & 1 \\
\hline 6 & Bumi Resources Tbk & Unqualified opinion & 1 \\
\hline 7 & Bayan Resources Tbk & Unqualified opinion & 1 \\
\hline 8 & Darma Henwa Tbk & Unqualified opinion & 1 \\
\hline 9 & Delta Dunia Makmur Tbk & Unqualified opinion & 1 \\
\hline 10 & Golden Energy Mines Tbk & Unqualified opinion & 1 \\
\hline 11 & Garda Tujuh Buana Tbk & Unqualified opinion & 1 \\
\hline 12 & Harum Energy Tbk & Unqualified opinion & 1 \\
\hline 13 & Indo Tambangraya Megah Tbk & Unqualified opinion & 1 \\
\hline 14 & Resources Alam Indonesia Tbk & Unqualified opinion & 1 \\
\hline 15 & Mitrabara Adiperdana Tbk & Unqualified opinion & 1 \\
\hline 16 & Samindo Resources Tbk & Unqualified opinion & 1 \\
\hline 17 & Perdana Karya Perkasa Tbk & Unqualified opinion & 1 \\
\hline 18 & Tambang Batubara Bukit Asam Tbk & Unqualified opinion & 1 \\
\hline 19 & Petrosea Tbk & Unqualified opinion & 1 \\
\hline 20 & Toba Bara Sejahtera Tbk & Unqualified opinion & 1 \\
\hline 21 & Ratu Prabu Energy Tbk & Unqualified opinion & 1 \\
\hline 22 & Elnusa Tbk & Unqualified opinion & 1 \\
\hline 23 & Energy Mega Persada Tbk & Unqualified opinion & 1 \\
\hline 24 & Surya Esa Perkasa Tbk & Unqualified opinion & 1 \\
\hline 25 & Medco energi Internasional Tbk & Unqualified opinion & 1 \\
\hline 26 & Radiant Utama Interinsco Tbk & Unqualified opinion & 1 \\
\hline 27 & Aneka Tambang Tbk & Unqualified opinion & 1 \\
\hline 28 & Cita Mineral Investindo tbk & Unqualified opinion & 1 \\
\hline 29 & Citra kebun Raya Agri Tbk & Disclaimerof Opinion & 0 \\
\hline 30 & Central Omega Resources Tbk & Unqualified opinion & 1 \\
\hline 31 & Vale Indonesia Tbk & Unqualified opinion & 1 \\
\hline 32 & J Resources Asia Pasifik Tbk & Unqualified opinion & 1 \\
\hline 33 & Timah Tbk & Unqualified opinion & 1 \\
\hline 34 & Citatah Tbk & Unqualified opinion & 1 \\
\hline
\end{tabular}




\begin{tabular}{|l|l|c|c|}
\hline 35 & Mitra Investindo Tbk & Unqualified opinion & 1 \\
\hline
\end{tabular}

Berdasarkan tabel 3 di atas opini audit perusahaan manufaktur subsektor pertambangan pada tahun 2017, sebanyak 34 perusahaan memberi pendapat wajar tanpa pengecualian (Unqualified opinion), yang dimana diberi kode dummy 1, sedangkan perusahaan yang memberi pendapat selain wajar tanpa pengecualian yaitu opini Disclaimerof Opinion, Yang dimana diberi kode dummy 0 .

\section{Audit Delay Sub Sektor Pertambang Periode 2017}

Audit delay merupakan jarak waktu antara tanggal laporan keuangan sampai tanggal saat auditor mengeluarkan laporan audit, dan semakin lama auditor menyelesaikan laporan auditnya maka audit delay semakin panjang.

\section{Tabel 4}

Audit Delay Sub Sektor Pertambangan Periode 2017

\begin{tabular}{|c|c|c|}
\hline No & Nama Perusahaan & Audit Delay \\
\hline 1 & Adaro Energy Tbk & 59 \\
\hline 2 & Atlas Resources Tbk & 88 \\
\hline 3 & ATPK Resources Tbk & 172 \\
\hline 4 & Borneo Lumbung Energy \& Metal Tbk & 0 \\
\hline 5 & Baramulti Suksessarana Tbk & 50 \\
\hline 6 & Bumi Resources Tbk & 0 \\
\hline 7 & Bayan Resources Tbk & 85 \\
\hline 8 & Darma Henwa Tbk & 122 \\
\hline 9 & Delta Dunia Makmur Tbk & 60 \\
\hline 10 & Golden Energy Mines Tbk & 59 \\
\hline 11 & Garda Tujuh Buana Tbk & 144 \\
\hline 12 & Harum Energy Tbk & 87 \\
\hline 13 & Indo Tambangraya Megah Tbk & 53 \\
\hline 14 & Resources Alam Indonesia Tbk & 86 \\
\hline 15 & Mitrabara Adiperdana Tbk & 59 \\
\hline 16 & Samindo Resources Tbk & 79 \\
\hline 17 & Perdana Karya Perkasa Tbk & 88 \\
\hline 18 & Tambang Batubara Bukit Asam Tbk & 67 \\
\hline 19 & Petrosea Tbk & 59 \\
\hline 20 & Toba Bara Sejahtera Tbk & 87 \\
\hline 21 & Ratu Prabu Energy Tbk & 77 \\
\hline 22 & Elnusa Tbk & 45 \\
\hline 23 & Energy Mega Persada Tbk & 180 \\
\hline 24 & Surya Esa Perkasa Tbk & 86 \\
\hline 25 & Medco energi Internasional Tbk & 96 \\
\hline 26 & Radiant Utama Interinsco Tbk & 85 \\
\hline 27 & Aneka Tambang Tbk & 68 \\
\hline 28 & Cita Mineral Investindo tbk & 71 \\
\hline 29 & Citra kebun Raya Agri Tbk & 141 \\
\hline 30 & Central Omega Resources Tbk & 82 \\
\hline 31 & Vale Indonesia Tbk & 58 \\
\hline 32 & J Resources Asia Pasifik Tbk & 86 \\
\hline 33 & Timah Tbk & 59 \\
\hline 34 & Citatah Tbk & 81 \\
\hline 35 & Mitra Investindo Tbk & 87 \\
\hline
\end{tabular}




\section{Statistik Deskriptif}

Statistik deskriptif memberikan gambaran atau deskripsi suatu data yang dilihat dari nilai ratarata (mean), standar deviasi, maksimum, minimum, dan range (Ghozali, 2012).

\section{Tabel 5}

\section{Hasil Uji Statistik Deskriptif Industri} Finansial Descriptive Statistics

\begin{tabular}{|l|r|r|r|r|r|}
\hline & N & Minimum & Maximum & Mean & $\begin{array}{c}\text { Std. } \\
\text { Deviation }\end{array}$ \\
\hline Y & 35 & 0 & 180 & 80,17 & 37,528 \\
X1 & 35 & 11 & 18 & 15,31 & 1,659 \\
X2 & 35 & 0 & 1 &, 80 &, 406 \\
X3 & 35 & 0 & 1 &, 97 &, 169 \\
Valid N & 35 & & & & \\
(listwise) & & & & & \\
\hline
\end{tabular}

Berdasarkan tabel 5 di atas menunjukkan dari sebanyak 35 sampel, nilai minimal audit delay 0 hari dan nilai maximal audit delay 180 hari dengan ratarata sebesar 80,17 hari dan standar devisa sebesar 37,528. Tampak bahwa rata-rata audit delay perusahaan masih dibawah 90 hari kalender yang merupakan batas yang ditetapkan bapepam, terlihat juga bahwa terdapat perusahaan yang terlambat karena mempunyai audit delay di atas 90 hari.

Dari sebanyak 35 sampelnilai minimal ukuran perusahaan 11 dan nilai maximal ukuran perusahaan 18 dengan rata-rata sebesar 15,13 dan standar deviasi sebesar 1,659. Jika dilihat data sebelum diolah yang diproksi dari total aset, ukuran perusahaan tampak terdapat rentang nilai yang relatif jauh.

Laba/rugi yang diukur menggunakan dummy dan nilai minimal laba/rugi perusahaan 0 dan nilai maximal laba/rugi perusahaan 1 dengan rata-rata sebesar 0,80 dan standar deviasi sebesar 0,406. Jika dilihat dari data sebelumnya sebanyak 28 perusahaan yang mengalami laba dan 7 perusahaan yang mengalami rugi di perusahaan manufaktur subsektor pertambangan.

Opini audit yang diukur menggunakan dummy dan nilai minimal opini audit 0 dan nilai maximal opini audit 1 dengan rata-rata sebesar 0,97 dan standar deviasi sebesar 0,169. Jika dilihat dari data sebelumnya sebanyak 1 perusahaan yang mengalami opini selain wajar tanpa pengecualian.

\section{Uji Asumsi Klasik \\ Uji Normalitas}

Uji normalitas yang digunakan adalah uji KolmogorovSmirnov (K-S). Dasar pengembalian keputusan dalam uji K-S adalah apabila nilai signifikansi $>0,05$ atau 5 persen maka data terdistribusi secara normal dan apabila nilai signifikansi $<0,05$ atau 5 persen maka data tidak terdistribusi normal (Ghozali, 2011:150).

a. Hasil pengujian dengan metode kolmogorov-smirnov sebagai berikut:

Tabel 6

Hasil Uji Normalitas

One-Sample Kolmogorov-Smirnov Test

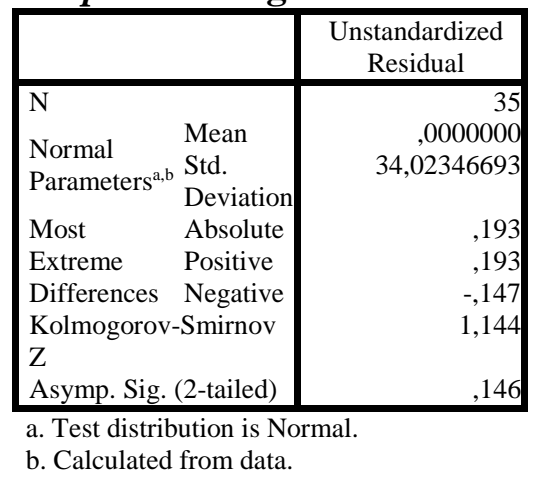

Hasil pengujian KolmogorovSmirnov yang dihasilkan menunjukkan nilai signifikansi sebesar 0,146 . Berdasarkan pengujian tersebut, nilai signifikansi lebih besar dari 0,05, maka data tersebut terdistribusi secara normal.

b. Hasil pengujian dengan grafik normal probability-plot sebagai berikut :

Uji normalitas residual dengan metode grafik, yaitu dengan melihat penyebaran data pada sumber diagonal pada grafik normal P-P plot ofregression standardized residual. 
Gambar 2

Grafik Normal Probability-Plot

Normal P-P Plot of Regression Standardized Residual

Dependent Variable: $Y$

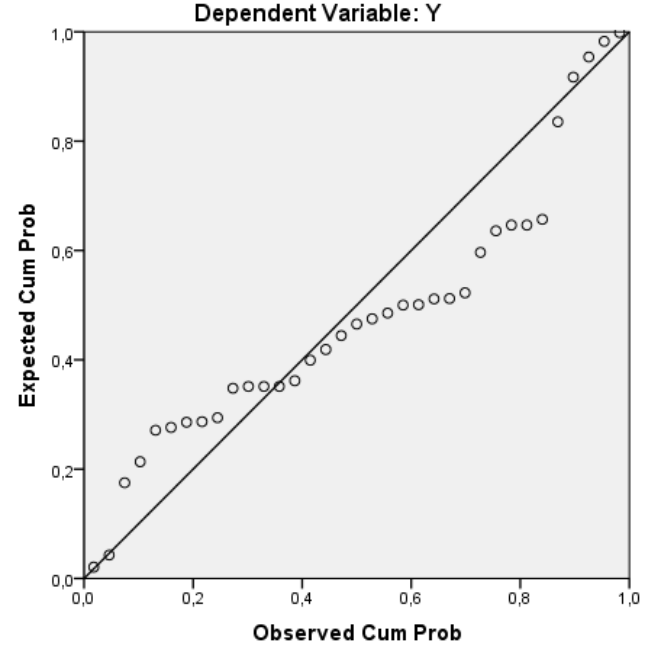

Dasar pengambilan keputusan untuk mendeteksi kenormalan adalah jika data menyebar disekitar garis diagonal dan mengikuti arah diagonal, maka model regresi memenuhi asumsi normalitas.Sebaliknya jika data menyebar jauh dari garis diagonal atau tidak mengikuti arah diagonal maka model regresi tidak memenuhi asumsi normalitas. Gambar 1 menunjukkan bahwa data menyebar disekitar garis diagonal atau mengikuti arah garis diagonal, maka data terdistribusi dengan normal dan model regresi telah memenuhi asumsi normalitas.

\section{Uji Multikolinearitas}

Multikolinearitas adalah keadaan dimana antara dua variabel independen atau lebih pada model regresi terjadi hubungan liniar yang sempurna atau mendekati sempurna (Ghozali, 2011:25). Model regresi yang baik mensyaratkan tidak adanya masalah multikolinearitas. Kriteria pengambilan keputusan yaitu jika nilai tolerance lebih dari 0,1 dan VIF kurang dari 10, maka tidak terjadi multikolinearitas.
Tabel 7

Uji Multikolinearitas

\begin{tabular}{|c|c|c|c|}
\hline \multicolumn{4}{|c|}{ Coefficients $^{\mathrm{a}}$} \\
\hline \multirow{2}{*}{\multicolumn{2}{|c|}{ Model }} & \multicolumn{2}{|c|}{ Collinearity Statistics } \\
\hline & & Tolerance & VIF \\
\hline \multirow[t]{3}{*}{1} & $\mathrm{X} 1$ & 826 & 1,211 \\
\hline & $\mathrm{X} 2$ &, 774 & 1,291 \\
\hline & $\mathrm{X} 3$ & 869 & 1,150 \\
\hline \multicolumn{4}{|c|}{ a. Dependent Variable: Y } \\
\hline
\end{tabular}

Pada tabel output di atas, dapat diketahui bahwa nilai tolerance dari ukuran perusahaan sebesar 0,826, laba/rugi perusahaan sebesar 0,774 dan opini audit sebesar 0,869. Sedangkan nilai VIF untuk ukuran perusahaan sebesar 1,211, laba/rugi perusahaan sebesar 1,291 dan opini audit sebesar 1,150. Nilai kedua variabel independen memiliki nilai tolerance lebih dari 0,1 dan nilai VIF kurang dari 10 sehingga dapat disimpulkan bahwa dalam model regresi tidak terjadi masalah multikolinearitas.

\section{Uji Heteroskedastisitas}

Uji heteroskedastisitas bertujuan untuk menguji apakah dalam model regresi terjadi ketidaksamaan antara varian dari residual suatu pengamatan ke pengamatan lain (Ghozali, 2011:139). Ada tidaknya heteroskedastisitas dalam persamaan regresi dapat dideteksi dengan menggunakan uji Glejser. Model regresi yang baik adalah tidak terjadi heteroskedastisitas. Jika signifikannya di atas tingkat kepercayaan 5\% maka dapat disimpulkan tidak terjadi heteroskedastisitas. Selain dengan menggunakan uji Glejser, menguji adanya heteroskedastisitas dapat dilakukan dengan melihat scatter plot. Heteroskedastisitas terjadi apabila pada scatter plot titiktitiknya mempunyai pola yang teratur baik menyempit, melebar maupun bergelombang. (Sunyoto, 2013:91). 


\section{Gambar 3}

\section{Uji Heteroskedastisitas}

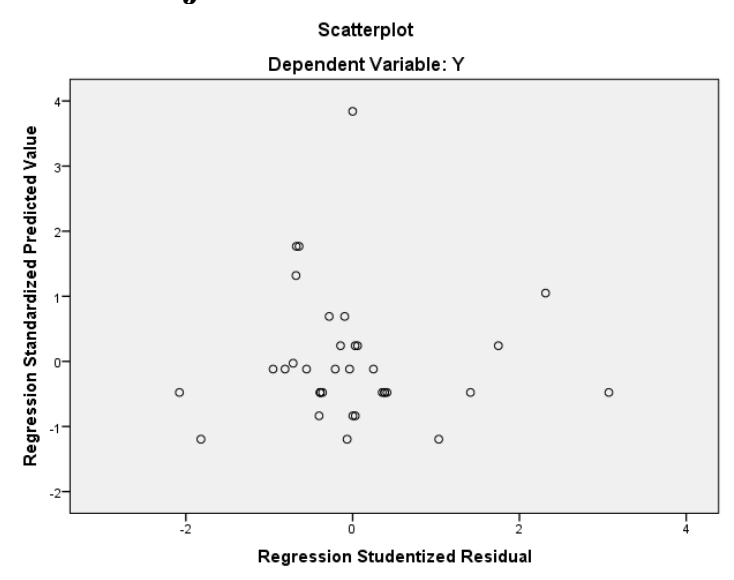

Grafik Scatter Plot menunjukkan bahwa data tersebar diatas dan dibawah angka 0 (nol) pada sumbu $\mathrm{Y}$ dan tidak terdapat satu pola yang jelas pada penyebaran data tersebut. Hal ini berarti terjadi masalah heteroskedastisitas pada model regresi.

\section{Uji Autokorelasi}

Uji autokorelasi bertujuan untuk mengetahui apakah dalam suatu regresi linear terdapat korelasi antara kesalahan pengganggu (residual) pada periode $t$ dengan kesalahan pengganggu pada periode $\mathrm{t} 1$ (periode sebelumnya) (Santoso, 2006:213). Dalam penelitian ini, uji autokorelasi menggunakan uji Durbin Watson (DW-Test), dimana dalam pengambilan keputusan melihat berapa jumlah sampel yang diteliti yang kemudian dilihat angka ketentuannya pada tabel Durbin Watson.

\section{Tabel 8}

Uji Autokorelasi

Model Summary ${ }^{\mathrm{b}}$

\begin{tabular}{|l|r|r|r|r|r|}
\hline Model & $\mathrm{R}$ & $\mathrm{R}$ Square & $\begin{array}{l}\text { Adjusted R } \\
\text { Square }\end{array}$ & $\begin{array}{l}\text { Std. Error of } \\
\text { the Estimate }\end{array}$ & Durbin-Watson \\
\hline 1 & $.422^{2}$ & .228 & .335 & 36.671 & 2.238 \\
\hline
\end{tabular}

a. Predictors: (Constant), X3, X1, X2

b. Dependent Variable: Y

Dari tabel di atas dapat diketahui bahwa nilai Durbin-Watson adalah sebesar 2,238. Nilai dL dan Du dapat diketahui pada tabel Durbin-Watson Pada signifikansi $0,05, \mathrm{n}=35$ dan $\mathrm{k}=3$. Di dapat $\mathrm{dL}=1,283$ dan $\mathrm{du}=1,653$. jadi dapat dihitung nilai 4-du= 2,347 dan 4$\mathrm{dL}=2,717$. Nilai Durbin-Watson sebesar 2,183 terletak pada daerah du $<$ DW $<4$-dU $(1,653<2,238<2,347)$ maka dapat disimpulkan data tidak terjadi autokorelasi.

\section{Analisis Pengaruh Ukuran Perusahaan, Laba/Rugi Perusahaan, dan Opini Audit Terhadap Audit Delay.}

\section{Analisi Regresi Linear Berganda}

Pengujian dilakukan dengan menggunakan analisis regresi linear berganda dengan menggunakan program Software Statical Package for Sosial Sciences (SPSS) Ver 21 for Windows. Hasil analisis regresi linear berganda dapat dilihat pada tabel sebagai berikut :

\section{Tabel 9}

\section{Koefisien Regresi Linear Berganda}

\begin{tabular}{|c|c|c|c|c|c|}
\hline \multirow[t]{2}{*}{ Model } & \multicolumn{2}{|c|}{$\begin{array}{l}\text { Unstandardized } \\
\text { Coefficients }\end{array}$} & \multirow{2}{*}{$\begin{array}{c}\text { Standardized } \\
\text { Coefficients }\end{array}$} & \multirow[t]{2}{*}{$\bar{T}$} & \multirow[t]{2}{*}{ Sig. } \\
\hline & B & $\begin{array}{c}\text { Std. } \\
\text { Error }\end{array}$ & & & \\
\hline $\begin{array}{ll}1 & \\
& \text { (Constant) }\end{array}$ & 214,934 & 63,614 & & 3,379 & ,002 \\
\hline $\mathrm{X} 1$ & $-5,687$ & 4,054 &,- 251 & 1,403 & ,171 \\
\hline $\mathrm{X} 2$ & $-12,795$ & 17,110 &,- 138 &,- 748 & , 460 \\
\hline X3 & $-38,532$ & 38,776 &,- 174 &,- 994 &, 328 \\
\hline
\end{tabular}

Dari persamaan di atas dapat diartikan sebagai berikut :

1. Nilai konstanta (a) adalah 214,934 ini dapat diartikan jika ukuran perusahaan, laba/rugi perusahaan dan opini audit nilainya 0 , maka audit delay adalah sebesar 214,934 satuan dengan asumsi variabel independen lain nilainya tetap.

2. Nilai koefisien regresi variabel ukuran perusahaan adalah $-5,687$ ini dapat diartikan jika variabel independen lain nilainya tetap dan ukuran perusahaan mengalami kenaikan 1\%, maka audit delay akan mengalami penurunan sebesar 5,687\%. Koefisien bernilai negatif artinya terjadi hubungan negatif 
antara ukuran perusahaan dengan audit delay.

3. Nilai koefisien regresi variabel laba/rugi perusahaan adalah $-12,795$ ini dapat diartikan jika variabel independen lain nilainya tetap dan laba/rugi mengalami kenaikan $1 \%$, maka audit delay akan mengalami penurunan sebesar $12,795 \%$. Koefisien bernilai negatif artinya terjadi hubungan negatif antara laba/rugi dengan audit delay.

4. Nilai koefisien regresi variabel opini audit adalah -38,532 ini dapat diartikan jika variabel independen lain nilainya tetap dan opini audit mengalami kenaikan 1\%, maka audit delay akan mengalami penurunan sebesar $38,532 \%$. Koefisien bernilai negatif artinya terjadi hubungan negatif antara opini auditdengan audit delay.

5. Jika dilihat dari persamaan regreasi $\mathrm{Y}=$ 214,934-5,687 $\mathrm{X}_{1}-12,795 \quad \mathrm{X}_{2}-38,532$ $\mathrm{X}_{3}$, maka pengaruh yang paling dominan terhadap audit delay (Y) adalah opini audit.

\section{Pengujian Hipotensis Uji t (Koefisien)}

Menurut Priyatno, 2010:86 Uji t

(Koefisien) berfungsi untuk menguji ada tidaknya penagaruh secara parsial current ratio dan pertumbuhan perusahaan terhadap harga saham. Untuk melakukan uji $\mathrm{t}$ dilakukan dengan membandingkan $t_{\text {hitung }}$ dengan $t_{\text {tabel }}$ adalah sebagai berikut:

\section{Tabel 10}

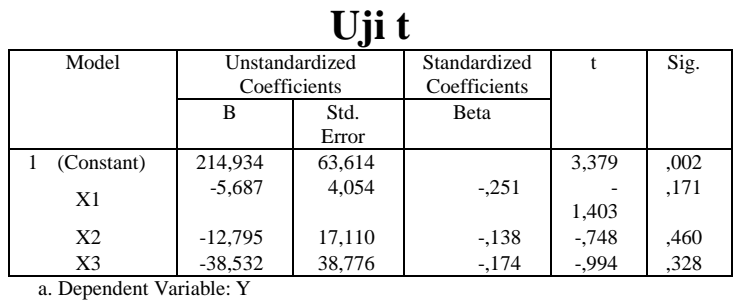

\section{Tabel 11}

Uji F

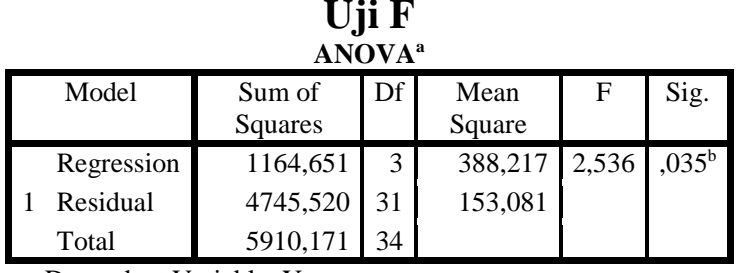

a. Dependent Variable: Y

b. Predictors: (Constant), X3, X1, X2
1. Dari output Pengujian variabel ukuran perusahaan $\left(\mathrm{X}_{1}\right)$

Dimana dilihat dari output didapat thitung sebesar -1,403 dan tabel yang dapat dilihat di tabel statistik yang signifikan $0,002 / 2=0,001$ dengan derajat kebebasan $\mathrm{df}=\mathrm{n}-\mathrm{k}-1$ atau $\mathrm{df}=35-3$ $-1=31$ hasil yang diproleh untuk $t_{\text {tabel }}$ sebesar $\pm 3,375$. Jadi nilai $t_{\text {hitung }}-1,403$ berada diantara $t_{\text {tabe }} l$ atau $-3,375 \leq t_{\text {tabel }}$ $\leq 3,375$ dan signifikasi lebih kecil dari $0,05(0,001<0,005)$, maka $\mathrm{H}_{0}$ diterima dan menolak $\mathrm{H}_{\mathrm{a}}$ dengan demikian dapat disimpulkan bahwa ukuran perusahaan secara parsial tidak berpengaruh terhadap audit delay.

2. Pengujian variabel laba/rugi perusahaan $\left(\mathrm{X}_{2}\right)$

Dimana dapat dilihat dari output $t_{\text {hitung }}$ sebesar -0,748 dan $t_{\text {tabel }}$ yang dapat dilihat ditabel statistik pada signifikasi $0,002 / 2=0,001$ dengan derajat kebebasan $\mathrm{df}=\mathrm{n}-\mathrm{k}-1$ atau $35-3-1$ $=31$ hasil yang diproleh untuk $\mathrm{t}_{\text {tabel }}$ sebesar $\pm 3,375$. Jadi nilai $t_{\text {hitung }}-0,748$ berada diantara $t_{\text {tabel }}$ atau $-3,375 \leq t_{\text {tabel }}$ $\leq 3,375$ dan signifikasi lebih kecil dari $0,05(0,001<0,005)$, maka $\mathrm{H}_{0}$ diterima dan menolak $\mathrm{H}_{\mathrm{a}}$ dengan demikian dapat disimpulkan bahwa laba/rugi perusahaan secara parsial tidak memiliki pengaruh terhadap audit delay.

3. Pengujian variabel opini audit (X3)

Dimana dapat dilihat dari output $\mathrm{t}_{\text {hitung }}$ sebesar -0,994 dan $t_{\text {tabel }}$ yang dapat dilihat ditabel statistik pada signifikasi $0,05 / 2=0,025$ dengan derajat kebebasan $\mathrm{df}=\mathrm{n}-\mathrm{k}-1$ atau $35-3-1$ $=31$ hasil yang diproleh untuk tabel sebesar $\pm 3,375$. Jadi nilai thitung $-0,994$ berada diantara $\mathrm{t}_{\text {tabel }}$ atau-3,375 $\leq \mathrm{t}_{\text {tabel }} \leq$ 3,375 dan signifikasi lebih kecil dari $0,05(0,001<0,005)$, maka $\mathrm{H}_{0}$ diterima dan menolak $\mathrm{H}_{\mathrm{a}}$ dengan demikian dapat disimpulkan bahwa opini audit secara parsial tidak memiliki pengaruh terhadap audit delay. 


\section{Pengujian Hipotesis 1 Uji F (Anova)} Menurut Priyanto, 2010:83-84 Uji

$\mathrm{F}$ (Anova) yaitu uji koefisien regresi secara simultan untuk menguji adanya pengaruh atau tidaknya dan signifikansi ukuran perusahaan,laba/rugi perusahaan dan opini audit terhadap audit delay $\mathrm{Uji} F$ dengan

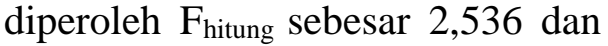
$F_{\text {tabel }}$ yang dilihat pada tabel statistik dengan tingkat signifikan 0,05 dengan df 1 (jumlah variabel -1$)=3$ dan df $_{2}=(n-k-1)$ atau $35-3-1=31$ adalah sebesar 3,327 jadi kesimpulannya $\mathrm{F}_{\text {hitung }}<\mathrm{F}_{\text {tabel }}(2,536<$ 2,911) dan tingkat signifikan lebih kecil $0,05(0,035<0,05)$, maka $\mathrm{H}_{0}$ diterima dan menolak $\mathrm{H}_{\mathrm{a}}$. Dengan demikian ukuran perusahaan, laba/rugi perusahaan dan opini audit tidak berpengaruh secara simultan terhadap audit delay.

\section{Koefisien Determinasi}

\section{Tabel 12}

\section{Analisis Koefisien Determinasi}

\begin{tabular}{|c|c|c|c|r|}
\hline \multicolumn{5}{|c|}{ Model Summary } \\
\hline Model & $\mathrm{R}$ & $\begin{array}{c}\mathrm{R} \\
\text { Square }\end{array}$ & $\begin{array}{c}\text { Adjusted } \mathrm{R} \\
\text { Square }\end{array}$ & $\begin{array}{c}\text { Std. Error of } \\
\text { the Estimate }\end{array}$ \\
\hline 1 &, $422^{\mathrm{a}}$ &, 228 &, 335 & 35,632 \\
\hline \multicolumn{5}{|c|}{ a. Predictors: (Constant), X3, X1, X2 } \\
\hline
\end{tabular}

Berdasarkan tabel di atas diperoleh angka $\mathrm{R}^{2}$ sebesar 0,228 atau $22,8 \%$. Hal ini menujukkan bahwa terjadi hubungan kuat antara ukuran perusahaan, laba/rugi perusahaan dan opini audit terhadap audit delay.

\section{Pembahasan}

\section{Pengaruh Ukuran Perusahaan, Laba/Rugi Perusahaan, dan Opini Audit Terhadap Audit Delay (Secara Simultan)}

Untuk mengetahui ada tidaknya pengaruh ukuran perusahaan, laba/rugi perusahaan, dan opini audit terhadap audit delay, maka dilakukan uji $\mathrm{F}$ (ANOVA) hasil pengujian ANOVA pada tabel diproleh nilai $F_{\text {hitung }}$ sebesar 2,536 dan $F_{\text {tabel }}$ yang dilihat pada tabel statistik dengan signifikan 0,05 dengan $\mathrm{df}_{1}=$ (jumlah variabel -1$)$ atau $4-1=3, \mathrm{df}_{2}=(\mathrm{n}-\mathrm{k}-1)$ atau atau $35-3-1=31$ adalah sebesar 3,327 jadi kesimpulannya $F_{\text {hitung }}<\mathrm{F}_{\text {tabel }}(2,536<$ 2,911) dan tingkat signifikan lebih kecil $0,05(0,035<0,05)$, maka $\mathrm{H}_{0}$ diterima dan menolak $\mathrm{H}_{\mathrm{a}}$. Dengan demikian ukuran perusahaan, laba/rugi perusahaan dan opini audit tidak berpengaruh secara simultan terhadap audit delay. Sama dengan penelitian Arisudhana (2012) ukuran perusahaan, laba/rugi perusahaan, dan opini audit tidak berpengaruh secara simultan terhadap audit delay. Sedangkan berbeda dengan Arifatun (2013) ukuran perusahaan, profitabilitas dan opini audit berpengaruh secara simultan terhadap simultan terhadap audit delay.

Nilai koefisian desterminasi Adjusted R Square adalah 0,228 (22,8\%). Hal ini menunjukkan bahwa variabel ukuran perusahaan, laba/rugi perusahaan dan opini audit mempunyai pengaruh terhadap audit delay sebesar 42,2\% sedangkan sisanya sebesar 77,2\% (100\% $22,8 \%$ ) dipengaruhi oleh faktor-faktor lain yang tidak termasuk dalam penelitian ini. Demikian juga dengan nilai $\mathrm{R}$ Square adalah 0,099 (9,9\%). Yang menunjukkan variasi perubahan audit delay sebesar $33,5 \%$ yang disebabkan pada ukuran perusahaan, laba/rugi perusahaan dan opini audit terhadap opini audit. Pada hasil uji $\mathrm{F}$ yang menyatakan bahwa tidak adanya pengaruh secara simultan.

\section{Pengaruh Ukuran Perusahaan Terhadap Audit Delay (Secara Parsial)}

Hasil penelitian ini menunjukkan ukuran perusahaan tidak berpengaruh negatif terhadap audit delay perusahaan subsektor pertambangan yang terdaftar di Bursa Efek Indonesia tahun 2017. Penelitian ini sama seperti penelitian terdahulu Saemargani (2015) yang menyatakan ukuran perusahaan tidak mempunyai pengaruh yang signifikan terhadap audit delay, Arisudhana (2012) ukuran perusahaan tidak mempunyai pengaruh yang signifikan terhadap audit delay, dan berbeda dari penelitian Arifatun (2013) ukuran perusahaan berpengaruh signifikan terhadap audit delay dan 
penelitian Kartika (2009) ukuran perusahaan mempunyai pengaruh dan negatif signifikan terhadap audit delay,

Hal ini dibuktikan dengan nilai signifikandilihat dari output didapat thitung sebesar -1,403 dan tabel yang dapat dilihat di tabel statistik yang signifikan $0,002 / 2=$ 0,001 dengan derajat kebebasan $\mathrm{df}=\mathrm{n}-\mathrm{k}-$ 1 atau $\mathrm{df}=35-3-1=31$ hasil yang diproleh untuk $t_{\text {tabel }}$ sebesar $\pm 3,375$. Jadi nilai $t_{\text {hitung }}$ 1,403 berada diantara $t_{\text {tabel }}$ atau $-3,375 \leq$ $t_{\text {tabel }} \leq 3,375$ dan signifikasi lebih kecil dari $0,05(0,001<0,005)$.

\section{Pengaruh Laba/Rugi Perusahaan Terhadap Audit Delay (Secara Parsial)}

Hasil penelitian ini menunjukkan laba/rugi perusahaan tidak berpengaruh terhadap audit delay perusahaan subsektor pertambangan yang terdaftar di Bursa Efek Indonesia tahun 2017. Penelitian ini berbeda dari penelitian Kartika (2009) dan penelitian Utami (2006) laba/rugi perusahaan berpengaruh signifikan terhadap audit delay.

Hal ini dibuktikan dengan nilai signifikan dimana dapat dilihat dari output $t_{\text {thitung }}$ sebesar $-0,748$ dan $t_{\text {tabel }}$ yang dapat dilihat ditabel statistik pada signifikasi $0,002 / 2=0,001$ dengan derajat kebebasan $\mathrm{df}=\mathrm{n}-\mathrm{k}-1$ atau $35-3-1=31$ hasil yang diperoleh untuk $t_{\text {tabel }}$ sebesar $\pm 3,375$. Jadi nilai thitung $-0,748$ berada diantara $t_{\text {tabel }}$ atau $-3,375 \leq t_{\text {tabel }} \leq 3,375$ dan signifikasi lebih kecil dari $0,05(0,001<0,005)$.

\section{Pengaruh Opini Audit Terhadap Audit Delay (Secara Parsial)}

Hasil penelitian ini menunjukkan opini audit tidak berpengaruh terhadap audit delay perusahaan sub sektor pertambangan yang terdaftar di Bursa Efek Indonesia tahun 2017. Penelitian ini sama seperti penelitian terdahulu Saemargani (2015) tidak mempunyai pengaruh yang signifikan terhadap audit delay, penelitian Yulianti (2011) opini audit tidak mempunyai pengaruh yang signifikan terhadap audit delay dan penelitian Lestari (2010) yang menyatakan opini audit tidak mempunyai pengaruh yang signifikan terhadap audit delay dan berbeda dari penelitian Arifatun (2013) opini audit berpengaruh signifikan terhadap audit delay dan penelitian Kartika(2009) opini audit mempunyai pengaruh negatif dan signifikan terhadap audit delay.

Hal ini dibuktikan dengan nilai signifikan dimana dapat dilihat dari output $t_{\text {hitung }}$ sebesar $-0,994$ dan $t_{\text {tabel }}$ yang dapat dilihat ditabel statistik pada signifikasi $0,05 / 2=0,025$ dengan derajat kebebasan $\mathrm{df}$ $=\mathrm{n}-\mathrm{k}-1$ atau $35-3-1=31$ hasil yang diproleh untuk $t_{\text {tabel }}$ sebesar $\pm 3,375$. Jadi nilai thitung $-0,994$ berada diantara $t_{\text {tabel }}$ atau$3,375 \leq t_{\text {tabel }} \leq 3,375$ dan signifikasi lebih kecil dari $0,05(0,001<0,005)$.

\section{KESIMPULAN DAN SARAN 4.1 Kesimpulan}

Berdasarkan hasil analisis dan pembahasan yang telah dilakukan pada penelitian sebelumnya, maka peneliti dapat menarik kesimpulan bahwa berdasarkan hasil pengujian antara pengaruh ukuran perusahaan, laba/rugi perusahaan, dan opini audit Terhadap audit delay.

a. Berdasarkan hasil hipotesis secara parsial (uji t) dilihat dari output didapat $t_{\text {hitung }}$ sebesar -1,403 dan $t_{\text {tabel }}$ yang dapat dilihat di tabel statistik yang signifikan $0,002 / 2=0,001$ dengan derajat kebebasan $\mathrm{df}=\mathrm{n}-\mathrm{k}-1$ atau $\mathrm{df}=35-3$ $-1=31$ hasil yang diproleh untuk $t_{\text {tabel }}$ sebesar $\pm 3,375$. Jadi nilai $t_{\text {hitung }}-1,403$ berada diantara $t_{\text {tabel }}$ atau $-3,375 \leq t_{\text {tabel }}$ $\leq 3,375$ dan signifikasi lebih kecil dari $0,05(0,001<0,005)$. Demikian dapat disimpulkan bahwa ukuran perusahaan secara parsial tidak berpengaruh negatif terhadap audit delay.

b. Berdasarkan hasil hipotesis secara parsial (uji t) Dimana dapat dilihat dari output $\mathrm{t}_{\text {hitung }}$ sebesar $-0,748$ dan $\mathrm{t}_{\text {tabel }}$ yang dapat dilihat ditabel statistik pada signifikasi $0,002 / 2=0,001$ dengan derajat kebebasan $\mathrm{df}=\mathrm{n}-\mathrm{k}-1$ atau 35 $-3-1=31$ hasil yang diproleh untuk $t_{\text {tabel }}$ sebesar $\pm 3,375$. Jadi nilai thitung0,748 berada diantara $t_{\text {tabel }}$ atau $-3,375 \leq$ 
$\mathrm{t}_{\text {tabel }} \leq 3,375$ dan signifikasi lebih kecil dari $0,05(0,001<0,005)$. demikian dapat disimpulkan bahwa laba/rugi perusahaan secara parsialtidak berpengaruhterhadap audit delay

c. Berdasarkan hasil hipotesis secara parsial (uji t)dimana dapat dilihat dari output $t_{\text {hitung }}$ sebesar $-0,994$ dan $t_{\text {tabel }}$ yang dapat dilihat ditabel statistik pada signifikasi $0,05 / 2=0,025$ dengan derajat kebebasan $\mathrm{df}=\mathrm{n}-\mathrm{k}-1$ atau 35 $-3-1=31$ hasil yang diproleh untuk $t_{\text {tabel }}$ sebesar $\pm 3,375$. Jadi nilai $t_{\text {hitung }}-$ 0,994 berada diantara $t_{\text {tabel }}$ atau $-3,375 \leq$ $\mathrm{t}_{\text {tabel }} \leq 3,375$ dan signifikasi lebih kecil dari $0,05(0,001<0,005)$. Demikian dapat disimpulkan bahwa opini audit secara parsial tidakberpengaruhterhadap audit delay

d. Berdasarkan hasil hipotesis secara simultan (Uji $F$ ) dengannilai f $f_{\text {hitung }}$ sebesar 2,536 dan $F_{\text {tabel }}$ yang dilihat pada tabel statistik dengan signifikan 0,05 dengan $\mathrm{df}_{1}=($ jumlah variabel -1$)$ atau $4-1=3, \mathrm{df}_{2}=(\mathrm{n}-\mathrm{k}-1)$ atau atau 35 3- $1=31$ adalah sebesar 3,327 jadi kesimpulannya $F_{\text {hitung }}<F_{\text {tabel }}(2,536<$ 2,911) dan tingkat signifikan lebih kecil $0,05 \quad(0,035<0,05)$ maka demikian ukuran perusahaan, laba/rugi perusahaan dan opini audit tidak berpengaruh secara simultan terhadap audit delay.

\subsection{Saran}

Saran Beberapa saran untuk penelitian selanjutnya sebagai berikut.

1. Penelitian selanjutnya dapat menambahkan variabel independen lain yang kemungkinan dapat lebih menjelaskan audit delay, seperti Return On Asset (ROA), Return On Equity (ROE), opini auditor atau pergantian auditor.

2. Penelitian selanjutnya dapat memperluas objek penelitian ke sektor industri manufaktur yang tergolong lebih luas atau menggunakan seluruh perusahaan yang terdaftar di Bursa Efek Indonesia.
Melakukan penelitian secara terpisah terhadap objek penelitian perusahaan finansial dan non-finansial.

\section{DAFTAR PUSTAKA}

Arifatun. 2013. Pengaruh ukuran perusahaan, profitabilitas perusahaan, ukuran auditor, dan opini audit terhadap audit delay (studi empiris pada perusahaan makanan dan minuman yang terdaftar di Bursa Efek Indonesia periode 2009-2011.

Arikunto, S. 2010. Prosedur Penelitian Suatu Pendekatan Praktik. Jakarta : Rineka Cipta

Ghozali. 2011. Aplikasi Analisis Multivariate Dengan Program SPSS. Semarang: Universitas Diponegoro.

Ikatan Akuntansi Indonesia (IAI). 2001. Standar profesional akuntan publik. Pernyataan standar auditing 29 SA seksi 508. Jakarta : IAI

Kartika, Ani. 2011. Faktor-Faktor Yang Mempengaruhi Audit Delay Pada Perusahaan Manufaktur Yang Terdaftar Di BEI. Tesis. Semarang: Universitas Stikubank.

Priyanto. 2010. Teknik Mudah dan Cepat Melakukan Analisis Data Penelitian

Priyanto. 2010. Teknik Mudah dan Cepat Melakukan Analisis Data Penelitian Dengan SPSS. Yogyakarta : PT Gava Media.

Santoso. 2006. Menggunakan SPSS Untuk Statistik Non Parametrik, Jakarta: PT. Elex Media Komputindo.

Sugiyono. 2013. Metode Penelitian Pendidikan Pendekatan Kuantitatif, Kualitatif, dan R\&D. Bandung: Alfabeta.

Sunyoto. 2013. Metodologi Penelitian Akuntansi. Bandung: PT. Refika Aditama Anggota Ikapi. 
Utami, Wiwik. 2006. Analisis Determinan Audit Delay Kajian Empiris di Bursa

Efek Jakarta.

\section{Www.Idx.Co.Id}

Yuliyanti, Ani. 2011. "Faktor-Faktor yang Berpengaruh terhadap Audit Delay (Studi Kasus pada Perusahaan Manufaktur yang Terdaftar di Bursa Efek Indonesia pada Tahun 2007-2008)". 